\title{
PERAN ETOS KERJA PETANI MUSLIM DALAM USAHA MENINGKATKAN PRODUKSI PADI PADA LAHAN IRIGASI SEDERHANA
}

\author{
Muchlis Mappangaja ${ }^{1}$, Syafiuddin Saleh ${ }^{2}$ \\ ${ }^{1}$ Dosen Prodi Hukum Ekonomi Syariah FAI Unismuh Makassar \\ ${ }^{1}$ Dosen Prodi Pertanian Unismuh Makassar
}

\begin{abstract}
Abstrak
Penelitian ini bertujuan untuk menemukan cara untuk meningkatkan produksi dan pendapatan petani melalui pengelolaan dan pengelohan lahan sawah irigasi sederhana di Kabupaten Gowa Sulawesi selatan. Jenis penelitian yaitu variabel kuantitatif yang digabung dengan variabel kualitatif, dengan pendekatan model PLS(Partial Least Squares),yaitu dengan peran etos kerja petani berbasis Islami(petani muslim) dapat meningkatkan produktivitas kerja petani dan akan meningkatkan produksi lahan.
\end{abstract}

Hasil yang akan dicapai: Diduga produksi padi pada lahan non produktif saat sekarang(2016-2017) antara 0-3 ton/Ha/MT, dengan hasil peneltian melalui etos kerja petani diduga akan meningkatkan produksi menjadi 5 ton/ ha /musim.

Hal yang sifatnya dugaan awal dianalisis dengan pendekatan hipotesis serta melakukan pengujian statistik. Kekuatan pokok yang menjadi sasaran penelitian adalah membentuk kelompok tani di lokasi sawah yang statusnya irigasi sederhana dan pada sisi lain dukungan teknik irigasi sangat menentukan, penelitian tersebut dapat diyakini akan mendorong peningkatan produksi tanaman pangan. Beberapa potensi untuk memacu kinerja petani dalam mengusahakan lahannya yang tidak produktif menjadi produktif adalah adanya, niat, akhlaq, ilmu dan pengamalan ke empat komponen dasar tersebut, merupakan kekuatan yang sangat kuat untuk melakukan perubahan khususnya pengelolaan lahan irigasi sederhana menjadi lebih produktif, dan dari empatnya yang sangat dominan adalah perilaku akhlaq yang mulia pada para petani, karena itu sasaran utama adalah melakukan perubahan karakter melalui motivasi religi. dan budaya.

Kata Kunci: Etos Kerja, Petani Muslim, Produksi Padi

\begin{abstract}
This study aims to find ways to increase farmer's production and income through the management and management of irrigated lowland rice fields in Gowa regency of South Sulawesi. The type of research is quantitative variables combined with qualitative variables, with the approach of PLS model (Partial Least Squares), that is with the role of work ethic of Islami based farmers (Muslim farmers) can increase labor productivity of farmers and will increase land production.
\end{abstract}

Results to be achieved as research outcomes: It is assumed that rice production in nonproductive land now (2016-2017) between 0-3 ton / ha / MT, with the result of research through farmer work ethic is expected to increase production to 5 ton / ha / season.

The initial characteristic is analyzed by hypothetical approach and performs statistical test. The principal strengths that become the target of the research are to form farmer group in the location of irrigated lowland rice field and on the other hand the support of irrigation technique is very decisive, the research can be believed will encourage the increase of crop production food. Some of the potentials to spur farmers' performance in their unproductive lands are productive, intentional, akhlaq, science and practice to these four basic components, a powerful force for change especially the management of simple irrigated land to be more productive, and from the four which is very dominant is the noble behavior of noble to the farmers, therefore the main target is to change the character through religious motivation and culture

Keywords: Working Ethos, Muslim Farmers, Rice Production 


\section{WE- Jurnal Hukum Ekonomi Syariah | Vol. 1 | No. 2 | September 2017}

\section{A. PENDAHULUAN}

Indonesia sebagai Negara yang berpenduduk besar menghadapi tantangan yang cukup kompleks untuk memenuhi kebutuhan pangan penduduknya, berbagai kebijakan pemerintah yang telah digagas dan diprogramkan baik dalam rencana tahunan, jangka menengah, maupun jangka panjang pembangunan nasional, ketahanan pangan menjadi isu sentral dalam pembangunan serta merupakan program prioritas utama dalam pembangunan pertanian.

Bertolak dari firman Allah Swt pada QS.Ar-Rad: 11,

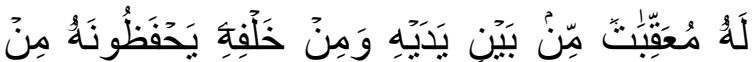

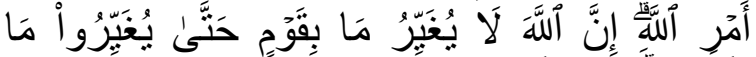

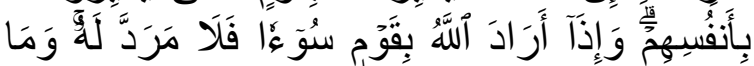

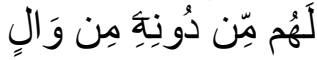

, Terjemahnya:

"Bagi manusia ada malaikatmalaikat yang selalu mengikutinya bergiliran, di muka dan di belakangnya, mereka menjaganya atas perintah Allah. Sesungguh-nya Allah tidak merubah keadaan sesuatu kaum sehingga mereka merubah keadaan yang ada pada diri mereka sendiri. Dan apabila Allah menghendaki keburukan terhadap sesuatu kaum, maka tak ada yang dapat menolaknya; dan sekali-kali tak ada pelindung bagi mereka selain Dia"

Pandangan ayat tersebut, mengabaikan kewajibannya sebagai menunjukkan bahwa dengan bekerja untuk berubah yang lebih baik dari keadaan semula adalah sebuah kemajuan, dijalankan dan dijadikan pegangan perubahan ini adalah hasil yang diperoleh dari kesungguhan kerja, untuk mendapatkan perubahan dari hasil usaha tersebut, tidak dapat berjalan sendiri tanpa adanya unsur keikhlasan dari seorang yang bekerja, keikhlasan adalah kekuatan dari dalam hati seorang yang tak surut dari terpaan godaan dari luar.

Melakukan perubahan tidak semudah membalik telapak tangan, namun dengan niat suci disertai prasangka optimis terhadap keberhasilan kerja adalah sebuah petunjuk dari-Nya untuk sukses, jika seorang petani dari awal berniat untuk melakukan pengelolaan sawahnya secara sempurna, dan tekad ini diteruskan dengan bekerja keras dan bersungguh-sungguh, maka padanya akan diberikan oleh Allah SWT limpahan pertolongan dan kemudahan urusan, kesungguhan yang dimaksud adalah melakukan pekerjaan dengan memanfaatkan dan mencurahkan semua potensi dari seorang, berupa potensi waktu, pikiran dan tenaga tanpa seorang petani muslim.Tuntunan ajaran Islam bagi kaum muslimin seperti itu, jika 


\section{Jurnal Hukum Ekonomi Syariah | Vol. 1 | No. 2 | September 2017}

sepenuhnya, tentu akan melahirkan produktifkan dan pada gilirannya akan kualitas kerja yang tinggi. Etika Islam menjadi suatu lahan yang bernilai ekonomi, sesungguhnya sudah sangat jelas dan jika demikian mari kita pecahkan komprehensif. Bekerja tidak hanya diukur masalahnya dengan memulai dari diri dari aspek-aspek yang bersifat lahiriah, sendiri (petani sawah), karena perubahan melainkan juga menyertakan dan bahkan itu bergantung pada semangat dan mengutamakan aspek-aspek batiniah atau kemauan yang bersangkutan, pertama spiritual itu. Islam tidak membolehkan jangan berharap kepada siapa saja, apapun dilakukan dengan pura-pura, mulailah bekerja tanpa pamri, tentu dengan seolah-olah, setengah-setengah, apalagi dukungan pengetahuan dan pengalaman palsu. Kepalsuan dilarang keras oleh ajaran dari masyarakat tani, serta bimbingan dari Islam. Agama samawi ini selalu menyeru kalangan akademik, yang dipadukan pada kejujuran, keadilan, dan kebenaran. dilapangan, pada waktunya nanti akan Atas dasar pandangan tersebut,jika selama terwujud suatu perubahan,di mana lahan ini kualitas kerja kita berbagai bagian tidur(non produktif,akan menjadi produktif. dirasakan masih rendah, sehingga tidak memberikan kepuasan pada masyarakat, misalnya produk-produk, kualitas pelayanannya masih rendah, maka yang perlu dilihat kembali adalah bagaimana sesungguhnya kaum muslimin selama ini mempersepsi ajaran Islam terkait dengan konsep bekerja ini. Oleh karena itu, telah diketahui secara nyata kondisi lahan irigasi yang non produktif, saat inmenjadi beban masyarakat dan pemerintah,karena diketahui bahwa dengan lahan tersebut sesunggunya berpotensi untuk di-

Peningkatan kebutuhan pangan, seiring dengan pertambahan jumlah penduduk dan peningkatan kesempatan kerja bagi penduduk guna memperoleh pendapatan yang layak. Ketidak seimbangan antara pertumbuhan permintaan pangan lebih cepat dari pertumbuhan penyediannya, permintaan yang meningkat cepat tersebut merupakan dampak peningkatan jumlah penduduk dan pertumbuhan ekonomi, yang meliputi daya beli masyarakat, pada sisi lain kapasitas produksi pangan nasional pertumbuhannya lambat, kondisi ini dipengaruhi oleh beberapa faktor, seperti ketersedian sumber daya lahan, tenaga kerja pertanian serta turunnya produktivitas lahan, ketidak 
seimbangan pertumbuhan permintaan dan per-tumbuhan kapasitas produksi nasional tersebut mengakibatkan adanya kecenderungan meningkatnya penyedian pangan nasional yang berasal dari impor, kebijakan pemerintah tersebut dipengaruhi oleh kehawatiran instabilitas nasional, dan kondisi ini diartikan sebagai ketidak mampuan penyedian pangan nasional, dengan kata lain penyedian dari produksi domestik belum stabil, dampak dari ketidakmampuan tersebut akan memunculkan masalah, antara lain pendapatan petani dari sektor lahan sawah cukup rendah, tenaga lokal dipedesaan yang tergolong muda lebih memilih kerjaan di perkotaan, atas dasar cepat mendapatkan uang walau hanya sebagai kuli bangunan, harga padi relatif rendah dibanding komoditi lainnya, kapasitas air irigasi desa/sederhana menjadi tidak efektif dan efisien dalam distribusi air irigasi.

Bertolak dari kondisi masalah tersebut maka salah satu pemikiran yang dapat diwujudkan, yaitu untuk mengatasi kekurangan tanaman pangan, melalui pemanfaatan lahan sawah non produktif menjadi produktif, dan lahan sawah tersebut dapat dikelola secara manual atau ataupun secara semi teknis. Pada sisi lain dukungan petani yang akan mengelola, harus dibangun integritasnya bahwa tanaman tersebut dapat di tingkatkan produksinya melalui peningkatan intensitas tanam, oleh karena itu diperlukan sosialisasi yang membangun maind set petani yang berbasis etos kerja (kecerdasan dan ketekunan serta kesungguhan untuk mengelola tanaman padi tersebut hingga dapat mewujudkan nilai produksi yang memadai.

Maka hasil penelitian ini akan menjawab beberapa hal berikut yaitu bagaimana lahan irigasi sederhana dapat menjadi lahan sawah yang lebih produktif di Kabupaten Gowa Sul-Sel? Bagaimana dukungan petani dan masyarakat untuk mengelola sawah irigasi sederhana menjadi sawah yang produktif di Kabupaten Gowa Sul-Sel? Bagaimana kebijakan pemerintah untuk memproduktifkan sawah beririgasi sederhana menjadi lebih produktif di Kabupaten Gowa Sul-Sel? Bagaimana hubungan variabel Etos Kerja Petani Muslim( §) terhadap variabel, Lahan Irigasi Sederhana ( $\eta$ ) dan Etos Kerja Petani Muslim( $\xi$ ) terhadap variabel Peningkatan Produksi(B) hubungan variabel Lahan Irigasi Sederhana ( $\eta$ ) terhadap variabel dan variabel Peningkatan Produksi(ß)? Bagaimana masyarakat dapat menyadari arti penting pemanfaatan lahan sawah yang bernilai ekonomi dan memambah jumlah produksi padi setiap tahunnya khususnya di Kabupaten Gowa Sualwesi Selatan?

\section{B. METODE PENELITIAN}

\section{Rancangan Penelitian}

Penelitian ini direncanakan di Kabuten Gowa Sulawesi Selatan, Sawah yang menjadi objek penelitian adalah 
sawah irigasi yang tidak produktif atau tidak dikelola oleh pemilik sawah, karena berbagai sebab, penelitian dilakukan dengan maksud agar lahan tersebut menjadi produktif dan petani mendapat pendapatan dari hasil garapan sawah , yang pada gilirannya dapat mensejahterakan keluarga petani khusus di Kabupaten Gowa. Masyarakat Petani Umumnya beragama Islam, yang berkelompok dalam organisasi kelompok tani dan kelompok petani pemakai Air(P3A), atas potensi dasar yang ada pada masyarakat tani tersebut, penelitimen coba melakukan motivasi kinerja yaitu meningkatkan etos kerja berbasis Islami kepada masyarakat tani muslim yang ada di dalam kelompok tani, pendekatan motivasi etos kerja petani diprediksi akan memacu kesungguhannya dalam mengelola lahan sawah yang selama ini tidak produktif.

\section{Teknik Pengambilan Sampel}

a. Probabilility sampling adalah tidak acak dan subjektif, yakni setiap anggota tidak memiliki peluang untuk menjadi sampel. Teknik pengambilan non probabilitas (non probability sampling methods) disebut juga dengan metode pemilihan sampel secara tidak acak.

b. Pengambilan sampel non probalitas (non probability sampling) adalah tidak acak dan subjektif, setiap anggota tidak memiliki peluang untuk menjadi sample. Teknik pengambilan sampel non probabilitas (non probability sampling methods) disebut juga dengan metode pemilihan sampel secara tidak acak (non randomly sampling methods).

\section{Metode Pengumpulan Data}

Data yang dikumpul adalah data kuantitaf dan kualitatif, penelitian ini menggunakan data kuantitatif, karena itu data di jarring dengan menggunakan teknik sebagai berikut :

a. Kuesioner, digunakan untuk menjaring data kuantitatif dari responden sebanyak .... orang petani, kuesioner dirancang disesuaikan dengan karakteristik daerah dan lokasi penelitian,.

b. Data sekunder dan profil daerah irigasi diperoleh dari instansi terkait dengan menghubungi langung sumber data

c. Data lapangan lainnya, berupa kondisi terakhir jaringan irigasi dan non Irigasi

\section{Instrumen Penelitian dan Skala}

\section{Pengukuran}

Instrumen utama dalam penelitian ini dalah kuesioner yang diperuntukkan bagi responden yaitu petani,Petani penggarap, petani pemilik.Hasil dari kuesioner diolah menurut syarat dan metode penelitian, yaitu dengan menggunakan metode (Partial Least Square) yang mengunakan sistem pengukuran dengan skala pengukuran Likert Summated rating dengan skala angka 1 (STS),2(TS),3 (B) 4 (S) dan 5 (SS) 
STS $=$ Sangat Tidak Setuju,

TS $=$ Tidak Setuju

$\mathrm{B}=$ Netral $/$ tidak tahu
$\mathrm{S}=$ Setuju

SS $=$ Sangat Setuju

5. Kerangka Konseptual

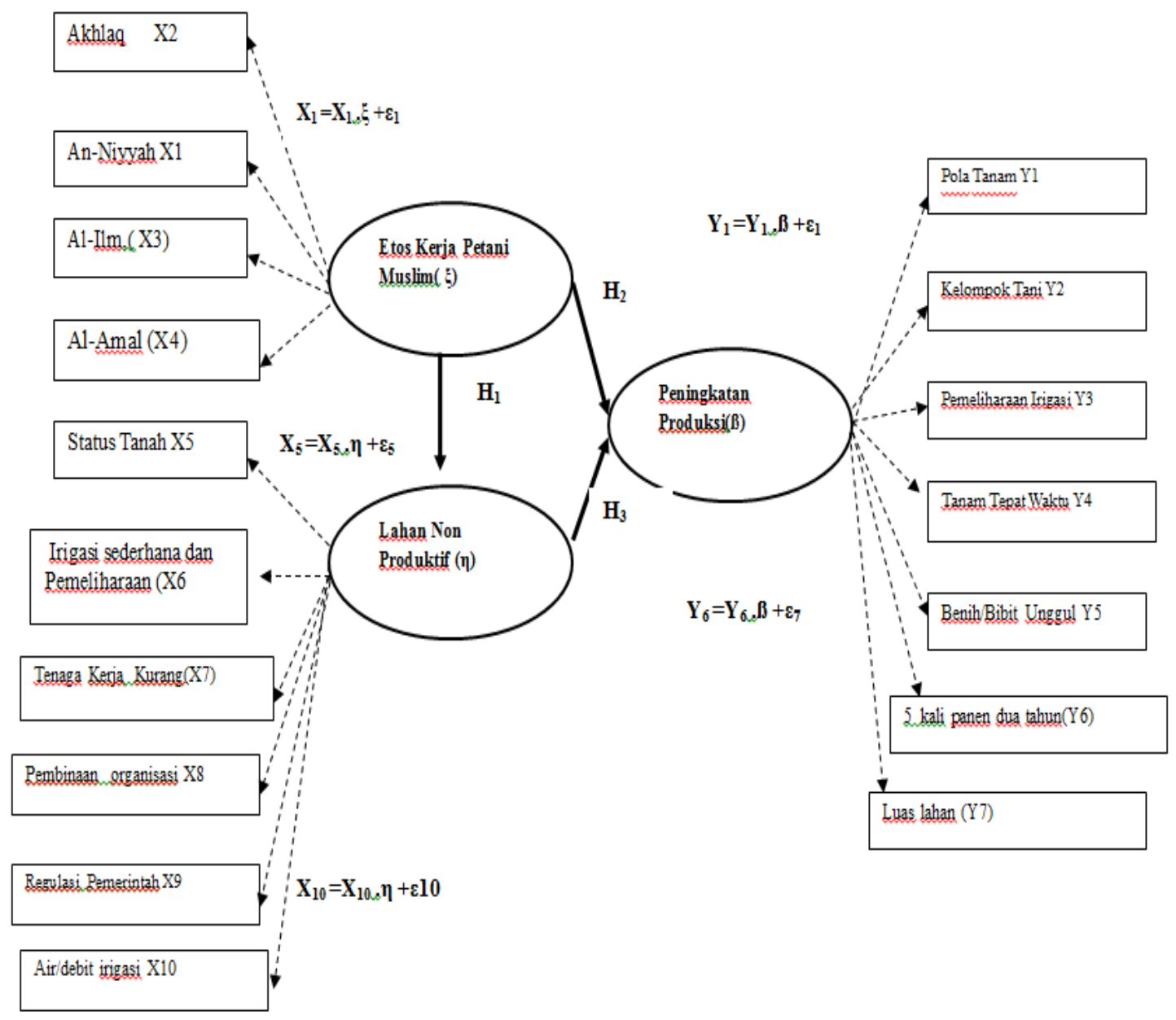




\section{E- Jurnal Hukum Ekonomi Syariah | Vol. 1 | No. 2 | September 2017}

\section{HASIL DAN PEMBAHASAN}

Bab ini disajikan pembahasan bab sebelumnya yang memberikan pandangan terhadap variabel etos kerja petani muslim yang berpengaruh terhadap variabel lahan non produktif dan berpengaruh terhadap variabel peningkatan produktif, dan variabel lahan non produktif berpengaruh terhadap variabel peningkatan produksi, ukuran pengaruh variabel tersebut dapat diuji terhadap evaluasi convergent validity dan discriminant validity, convergent validity memiliki tiga pengujian, yaitu reability item (validitas tiap indikator), composite reliability, dan average variance extracted (AVE). Adapun hasil pengolahann data yaitu sebagai berikut:

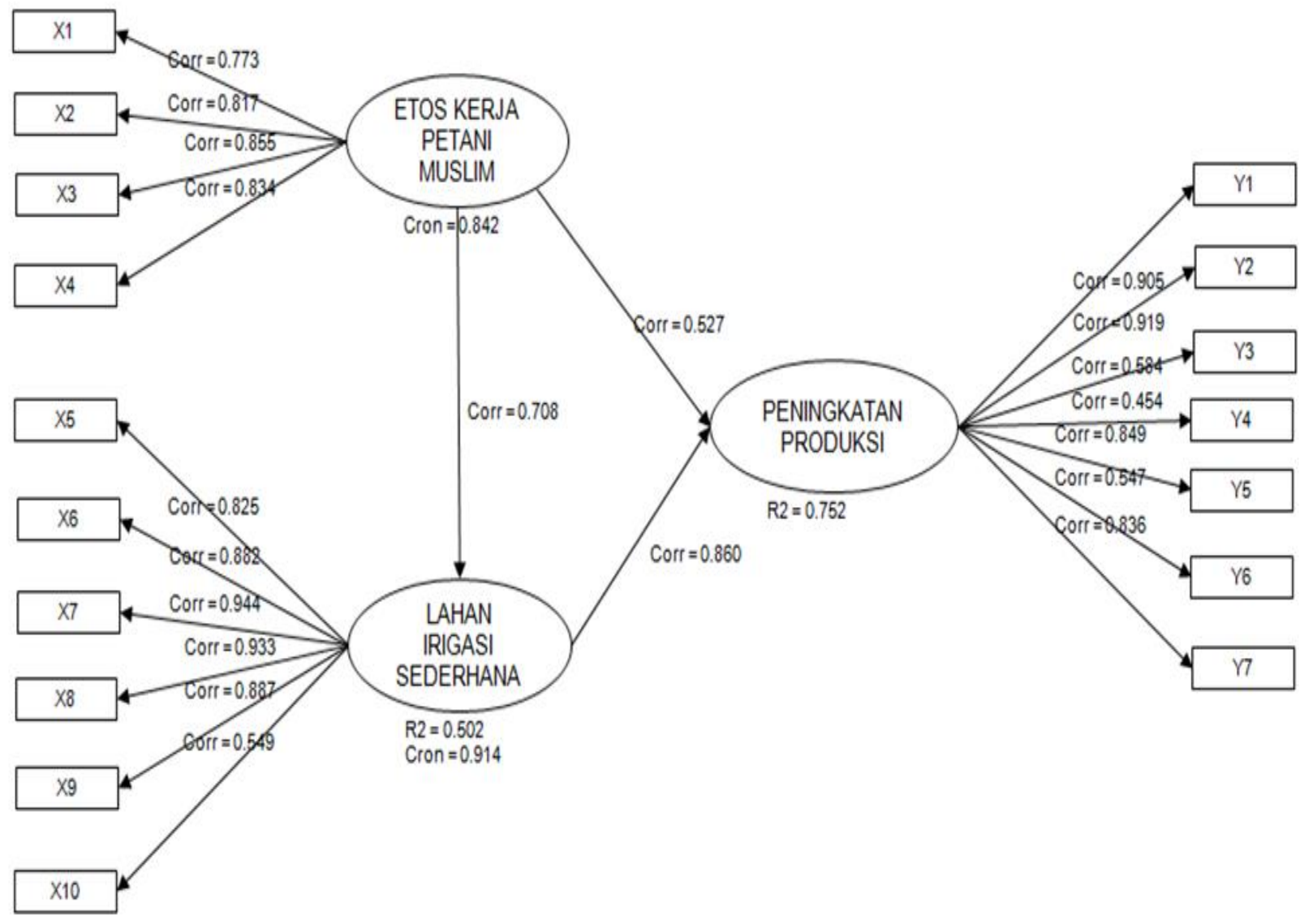

Berdasarkan hasil pengolahan data di variabel Lahan Irigasi sederhana dengan atas maka suatu indikator dikatakan nilai loading masing-masing $\mathrm{X} 5, \mathrm{X} 6, \mathrm{X} 7$ dan memiliki validitas I bila memiliki nilai loading $X 8$ dari table menunjukkan loading $>0.5$ factor lebih besar dari 0,5 di mana output (Valid), sementara variabel Peningkatan nilai loading sebesar,untuk $\mathrm{X} 1=0.773, \mathrm{X} 2$ produksi dengan nilai loading, untuk $\mathrm{Y} 1$, $=0.817, \mathrm{X} 3=0.855, \mathrm{X} 4=0.834$ dan semua $\mathrm{Y} 2, \mathrm{Y} 3, \mathrm{Y} 5, \mathrm{Y} 6$ dan $\mathrm{Y} 7>$ dari 0.5 kecuali nilai loading lebih besar dari 0.5 sehingga $\mathrm{Y} 4=0.454<$ dari 0.5 , hal ini menunjukan dapat dikatakatan indikator Valid, berikut secara rata-rata dinilai valid, selanjutnya 
untuk menguji signifikansi dari loading factor dapat dilihat dari nilai critical ratio di atas 2.0 terbukti dalam table correlation lebih besar dari 2.0, menunjukkan nilai loading signifikan sehingga dikatan valid.

Evaluasi terhadap composite reability atau reliabilitas konstrak yang digambarkan oleh table composite reliability, statistic yang digunakan adalah crombach's alpha dan D.G rho. Di mana Nilai Crombach's alpha dan D.G rho(PCA) di atas 0.7 ini menunjukkan konstrak memiliki reliabilitas atau keandala yang tinggi sebagai alat ukur, ini dapat dilihat pada table Composite Reliability(terlampir) di mana Crombach's Alpha variabel Etos Kerja Petani Muslim $=0,842>0,7$ dan Crombach's Alpha variabel Lahan irigasi sederhana= $0,914>0,7$, serta variabel Peningkatan Produksi dengan Nilai D.G rho(PCA) $=6,363$ dapat diukur dengan nilai critical Ratio, dari table sebesar 1,00 jadi D.G rho $>1$, kesimpulan data tersebut cukup reability.

Pengujian dengan cross loading, discriminant validity dapat diperiksa dengan membandingkan antara nilai AVE dengan kuadrat korelasi antarkonstrak. Hasil discriminant validity dari pengujian ini menunjukkan nilai AVE suatukonstrak haruslebih tinggi dibandingkan dengan kuadrat korelasi antara konstrak tersebut dengan konstrak lainnya (Table terlampir).

Perhatikan table terlampir (Correlation laten variable), di mana besarnya korelasi
Etos Kerja dengan Lahan Irigasi $0,708^{*} 0,708=0,527$. Nilai AVE dari konstruk Etos Kerja Petani 0.673,0,718 dan 0,561 lebih tinggi daripada kuadrat korelasi antara Etos kerja dan lahan irigasi sederhana dan kuadrat dan korelasi irigasi sederhana dan Peningkatan Produks,lebih tinggi dari kuadrat korelasi ,membuktikan sifat convergen validity yang baik.

\section{Menguji Hipotesis}

Hasil pengujian hipotesis dapat dilihat dari table 'inner model'. Berdasarkan table Path coefficient", di mana nilai t statistic untuk konstrak etos kerja0,882 dengan $\mathrm{P}$ Value $0,000<0,05$ atau dari nilai critical ratio (CR) 13,947,sehingga dapat dikatakan bahwa etos kerja Petani Muslim secara signifikan memiliki pengaruh positif terhadap peningkatan produksi. Nilai $t$ statistic untuk konstrak Lahan Irigasi Sederhana 0.957 dengan P-Value $0.000<$ 0.05, sehingga dikatakan bahwa Lahan irigasi sederhana secara signifikan berpengaruh positif terhadap peningkatan Produksi, sedang pengujian kebersamaan atau simultan antara konstrak etos kerja petani dan Lahan irigasi terhadap peningkatan produksi dapat dilihat dari statistic nilai $F$ dengan nilai $P$-Value 0.000 < 0.05, (-0.164 nilai Etos kerja, Lahan irigasi sederhana 0.976, hasil secara simultan etoskerja dan lahan irigasi sederhana tidak ber-pengaruh positif terhadap Peningkatan prosuksi. 
Berikut Equation of Model, petani muslim terhadap peningkatan

Peningkatan Produksi=

0,164098520078422, Etos Kerja Petani Muslim = 0,975817113128113, Lahan Irigasi Sederhana Besarnya konstribusi konstrak Etos Kerja Petani Muslim dan Lahan Irigasi Sederhana terhadap Peningkatan Produksi, dapat dilihat dari nilai koefisen jalur (Path Coefficient), sedangkan besarnya pengaruh atau varian yang mampu dijelaskan oleh kedua konstrak terhadap model, dapat dilihat darinilai $R^{2}$, berdasar nilai $R^{2}$ tersebut, diketahui bahwa konstrak Etos Kerja Petani Muslim menjelaskan variability konstrak lahan Irigasi Sederhana sebesar 0,502 $(50,2 \%)$ sedangkan sebesar $49,8 \%$ oleh konstrak lainnya.

Kontribusi terhadap niali $R^{2}$ ini dari setiap konstrak dapat dilihat table sebagai barikut. Berdasarkan kreteria Chin (1998) nilai $R^{2} \quad 0,752>-0.164$ dikelompokkan pengaruh yang rendah negatif. Dampak dan kontribusi dari variabel ke peningkatan produksi Variabel Lahan irigasi 0,860 > 0,527, ini menunjukkan bahwa ketersedian lahan sangat menunjang untuk peningkatan produksi.

\section{Analisis Masalah}

Bagaimana lahan sawah irigasi sederhana menjadi menjadi lahan sawah yang produktif di Kab. Gowa. Berdasar analisis data, menunjukkan bahwa lahan sawah Irigasi sederhana dan etos kerja produksi, kurang mengembirakan ini terlihat dari data, di mana koefisien jalur 0,976 (lahan irigasi) dan -0,164 (Etos kerja petani muslim) menunjukkan tidak signifikan untuk peningkatan produksi, untuk hal tersebut diperlukan upaya-upaya sebagai berikut :

Terhadap lahan, dikelola secara intensif melalui perbaikan irigasi untuk pengaturan pemberian dan pembagian air irigasi terhadap lahan sawah atau disebut peningkatan pengelolaan irigasi secara fisik. Melalui program pemerintah untuk peningkatan operasi dan pemeliharan irigasi,sertamembentuk petugas yang patuh dandisiplin dalam pengelolaan irigasi.

Terhadap Etos kerja diperlukan beberapa perlakuan sebagai berikut :

1. Pembentukan kelompok tani baik pada tingkat tersier maupun pada tingkat sekunder

2. Pembinaan kelompok tani dan P3A pada tingkat tersier

3. Mengaktifkan penyuluh pertanian dan Pembina irigasi dalam pembinaan irigasi

4. Peningkatan koordinasi antar instansi tekait untuk memperoleh daya dukung yang optimal dalam meningkatkan produksi tanaman pangan di Kab.Gowa.

5. Dukungan masyarakat melalui peningkatan sosialisai irigasi.

\section{Kesimpulan}


1. Bahwa etos kerja petani muslim mempunyai hubungan erat dengan keberadaan lahan irigasi sederhana, karena adanya petani dan ketersedian lahan dan irigasi, akan memberikan nilai (input) produksi, bahwa pada dugaan awal diperkirakan adanya lahan sawah non produktif, pada kenyataannya, berdasar pengamatan lapangan, bahwa kesadaran masyarakat atas lahan sawah tidak lagi membiarkan lahannya terlantar (tidak tergarap), ini suatu kemajuan kesadaran masyarakat di pedesaan yang secara keseruhan telah menggarap sawahnya walau hanya dengan irigasi tadah hujan, anggapan awal tersebut, menyebabkan perubahan arah penelitian, menjadi peningkatan produksi lahan irigasi sederhana yang berbasis etos kerja petani muslim.

2. Dukungan petani, jika dilihat secara individu Nampak memberikan respon positif atas upaya peningkatan produksi, kenyataan yang terlihat di mana keluarga petani bersama turun tangan saat pengelolaan sawah, mulai dari pembersihan lahan hingga tanam bibit, dukungan keluarga petani tidak lepas dan berlangsung secara kontinyu.

3. Kondisi produksi tanaman padi yang terjadi pada areal persawaan irigasi sederhana, secara umum diketahui oleh pemerintah, khususnya dinas pengelola sumber daya air, mengetahui secara saksama serta langkah yang dapat dilakukan, hanya karena keterbatasan dari berbagai factor sehingga program jangka pendek, menengah, maupun jangka panjang terkesan lambat, dan petanipun berjalan apa yang mampu dilakukan.

4. Secara analisis statistik diketahui variabel etos kerja petani muslim, mempunyai korelasi yang kuat terhadap variabel lahan irigasi sederhana, hubungan variabel tersebut didapat diartikan akan mempengaruhi secara signifikan karena besaran korelasi $0.708>$ 0.6 , tetapi dampak dan contibusi ke variabel lahan irigasi sederhana, dilihat dari sisi koefisien jalur dan kontribusi terhadap etos kerja menunjukkan kondisi normal dan layak. Pada analisis impact dan distribusi terhadap peningkatan produksi di mana koefisien jalur dari variabel lahan irigasi sederhana tidak memberikan nilai positif bahkan bernilai negatif terhadap variabel Etos kerja petani muslim. Hubungan variabel etos kerja petani muslim tidak berpengaruh signifikan di mana $0.527<0.6$ ini menunjukkan bahwa pengaruh etos kerja cukup lemah untuk mendorong 
peningkatan produksi, beberapa hal yang mempengaruhi anatar lain; kurangnya pembentu-kan kelompok tani dan pembinaan yang profesional baik kelompok tani maupun Perkumpulan Petani Pemakai Air (P3A), dukungan fasilitas infrastruktur untuk irigasi yang lebih teknis kurang memadai, sehingga pengaturan dan distribusi air irigasi tidak cukup atau sekali berlebihan, hal ini memacu terjadinya serangan hama dan kondisi tersebut sering menyebabkan gagal panen atau rendahnya produksi padi khususnya pada lahan irigasi non teknis (irigasi sederhana).

5. Pada umumnya masyarakat berkeinginan meningkatkan hasil produksi lahan sawahnya, upaya dilakukan secara maksimal melalui tuntunan penyuluh pertanian, antara lain mengikuti jadwal tanam yang dianjurkan,benih yang disepakati pada musyawarah tudang sipulung pada setiap awal tanam, namun upayadaripetani tersebut sering gagal dikarenakan hal sebagai berikut; Karena Ihan irigasi adalah lahan irigasi sederhana di mana pemberian air tidak dijamin teratur, sementara kelompok tani kurang terkoordinir disebabkan petani menyadari bahwa sawah yang dimiliki bukanlah irigasi teknis yang secara sempurna mendapat pelayanan pemeliharan irigasi secara kontinyu dari pemerintah, yang setiaptahunnya mendapat anggar-an pemeliharaan irigasi secara rotin, termasuk pembinaan kelompok tani yang terorganisir, hal ini diyakini oleh petani akan meningkat produksi tanaman setiaptahunnya.

\section{DAFTAR PUSTAKA}

Al- Qur'an. 2007. Departemen Agama Republik Indonesia. Bandung Syaamil Qur'an Hadist dan As Sunnah.

Anshori Muslich, Iswati Sri. 2009. Metodologi Penelitian Kuantitatif, AUP Surabaya.

Arif Ryan. 2012. Membudayakan Karakter Etosm Kerja Islami. Diakses: http://annur.org/2012/05/membudayakan-karakter-etos-kerja-islami,May8.2012/File under: Terbaru,Tsaqofah/Posted by : admin

Kusnendi. 2007. Model-Model Persamaan Struktural Satu dan Multigroup sampel dengan LISREL, Penerbit : Alfabeta, Bandung.

Purwantoro, 2011. Intensifikasi Padi Sawah Melalui Pengelolaan Tanaman Terpadu, Penerbit : PT Maraga Borneo Tarigas, Singkawang.

Perencanaan Irigasi Luwu Sulawesi Selatan, 1982,Dinas Pengairan Sulawesi selatan Ujung Pandang)

Pengembangan P3A dan Peranserta Petani dalam Pengelolaan Air Irigasi Di Indonesia, Ir.Soekarso Djunedi,1988), 
Salikin, Karwan A. 2003. Sistem Pertanian Berkelanjutan., Yogyakarta Kanisius.

Saragih Eliyas Sabastian, 2010, Pertanian Organik, Jakarta, Penerbit Penebar Swadaya.

Salikin, K.A. 2003, Sistem Pertanian Berkelanjutan. Kanisius, Jogyakarta.126 p.

Santoso Singgih, 2011. Structural Equation Modeling (SEM), Konsep dan Aplikasi dengan AMOS 18, Penerbit : PT.Elex Komputindo, Jakarta.

Suryana.A, 2007, Menelisik Upaya Menggapai Ketahanan Pangan Nasional, Badan Penelitian dan Pengembangan Pertanian, Jakarta.

Ulum, Misbahul, 2007. Model-model Kesejahteraan Sosial Islam Perspektif Normatif Filosofis dan Praktis. Fakultas Dakwah. UIN Sunan Kalijaga, Yogyakarta.

Wijanto Hari Setyo, 2008. Stuctural Equation Modeling, Penerbit : Graha IImu, Yogyakarta.

Yamin Sofyan.2011. Partial Least Square Path Modeling Penerbit: Salemba Infotek, Jakarta. 